Citation: Li, P., Mellor, S, Griffin, J, Waelde, C, Hao, L and Everson, R, (2014) 'Intellectual property and 3D printing: a case study on 3D chocolate printing' 9 (4) Journal of Intellectual Property Law and Practice 322-332; Li, P., Mellor, S, Griffin, J, Waelde, C, Hao, L and Everson, R, (2014) 1 GRUR Int 97 (Gewerblicher Rechtsschutz und Urheberrecht, Internationaler Teil)

\title{
Intellectual Property and 3D Printing: A case study on 3D chocolate printing
}

Phoebe Li, Stephen Mellor, James Griffin, Charlotte Waelde, Liang Hao, Richard Everson

\section{The authors}

Phoebe Li is a Lecturer at Sussex University. Stephen Mellor, James Griffin, Charlotte Waelde, Liang Hao, and Richard Everson are based at Exeter University.

\section{This article}

The emergence of 3D printing technology as a 'disruptive technology' challenges the existing intellectual property framework. Our paper considers one part of that framework - copyright - in the light of 3D printing, with a special focus on issues involving artistic works and liability for authorisation of infringement of copyright.

We consider a scenario concerning consumer co-creation arising from 3D chocolate printing technology developed at Exeter University. We discuss the production of two-dimensional artistic works into three dimensions; ownership; originality and substantial copying; authorship, term of protection, and authorisation of infringement.

We consider different business models for co-creation of 3D printing technology. We conclude that by resorting to collective bargaining mechanisms and collective licensing schemes akin to those developed in the UK and in Europe, the co-creators could be rewarded through mechanisms akin to benefit sharing.

Keywords

Additive manufacturing (AM)

3D printing; 3D chocolate printing

Intellectual property (IP)

Co-creation

Copyright

\section{ABSTRACT}

3D printing, also called Additive Manufacturing (AM), is a disruptive technology which 
Citation: Li, P., Mellor, S, Griffin, J, Waelde, C, Hao, L and Everson, R, (2014) 'Intellectual property and 3D printing: a case study on 3D chocolate printing' 9 (4) Journal of Intellectual Property Law and Practice 322-332; Li, P., Mellor, S, Griffin, J, Waelde, C, Hao, L and Everson, R, (2014) 1 GRUR Int 97 (Gewerblicher Rechtsschutz und Urheberrecht, Internationaler Teil)

some have argued has the potential to generate considerable economic and environmental benefits. However, and in order to realise the benefits of $3 \mathrm{D}$ printing, thought has to be given to the legal frameworks that support the manufacturing process from design to consumption. There are many areas of law that are relevant to this process including product liability, health and safety and environmental law. The one that will be considered in this paper is that of copyright, a branch of the law of intellectual property (IP). This paper examines 3D printing and selected copyright implications using a case study around the design and manufacture of 3D chocolate products. It also brings with it some particular challenges for the law of copyright around the co-creation process that it employs in the design of the chocolate products. The focus will be on three areas of the law of copyright, chosen because they lie at the heart of the chocolate business model, and because they are illustrative of just some of the challenges that are faced by both the law and $3 \mathrm{D}$ printing in responding to this new technology.

\section{INTRODUCTION}

3D printing has been defined by the ASTM F42 committee $^{1}$ as the process of joining materials to make objects from 3D model data, usually layer upon layer. This contrasts with subtractive manufacturing methodologies such as traditional machining. ${ }^{2}$ In the early years of $3 \mathrm{D}$ printing the more commonly used term to describe the process was Rapid Prototyping (RP), reflecting its main use at the time, as the manufacture of prototypes more quickly and easily than conventional means but which were not competitive for production. ${ }^{3}$ These prototypes were most commonly used as communication and inspection tools, where producing several physical models in a short time directly from computer solid models helped to shorten the production development steps. ${ }^{4}$ The terminology and definitions within the field in question have been much

\footnotetext{
* Corresponding author. E-mail addresses: Phoebe.Li@sussex.ac.uk (P. Li); sm270@exeter.ac.uk (S. Mellor); J.G.H.Griffin@exeter.ac.uk (J. Griffin); C.E.Waelde@exeter.ac.uk (C. Waelde); L.Hao@exeter.ac.uk (L.Hao); R.M.Everson@exeter.ac.uk (R. Everson).

1 ASTM Committee F42 on Additive Manufacturing Technologies was formed in 2009. The committees membership of approximately 100, has 3 technical subcommittees; all standards developed by F42 are published in the Annual Book of ASTM Standards, Volume 10.04. These standards will play a preeminent role in all aspects of additive manufacturing technologies.

2 T Campbell, C Williams, O Ivanova, and B Garrett, 'Could 3D Printing Change the World? ' (2011)

Technologies, Potential, and Implications of Additive Manufacturing. Strategic foresight report, Strategic Foresight Initiative, October.

3 C Chua, Rapid Prototyping: Principles and Applications (2nd ed, 2003). World Scientific: Singapore ; New Jersey.

4 EC Santos, M Shiomi, K Osakada, and T Laoui, 'Rapid manufacturing of metal components by laser forming' (2006) International Journal of Machine Tools and Manufacture 46 (12-13), 1459-1468.
} 
Citation: Li, P., Mellor, S, Griffin, J, Waelde, C, Hao, L and Everson, R, (2014) 'Intellectual property and 3D printing: a case study on 3D chocolate printing' 9 (4) Journal of Intellectual Property Law and Practice 322-332; Li, P., Mellor, S, Griffin, J, Waelde, C, Hao, L and Everson, R, (2014) 1 GRUR Int 97 (Gewerblicher Rechtsschutz und Urheberrecht, Internationaler Teil)

debated over the years, ${ }^{5}$ and are still the subject of discussion today. The reader may thus find a number of terms used interchangeably. In the realm of technical research, AM has been the most commonly used term, its authority demonstrated in its use by authors such as Terry Wohlers and by standards committees such as the ISO and ASTM. By contrast, in press publications such as The Economist the more commonly used term is $3 \mathrm{D}$ printing.

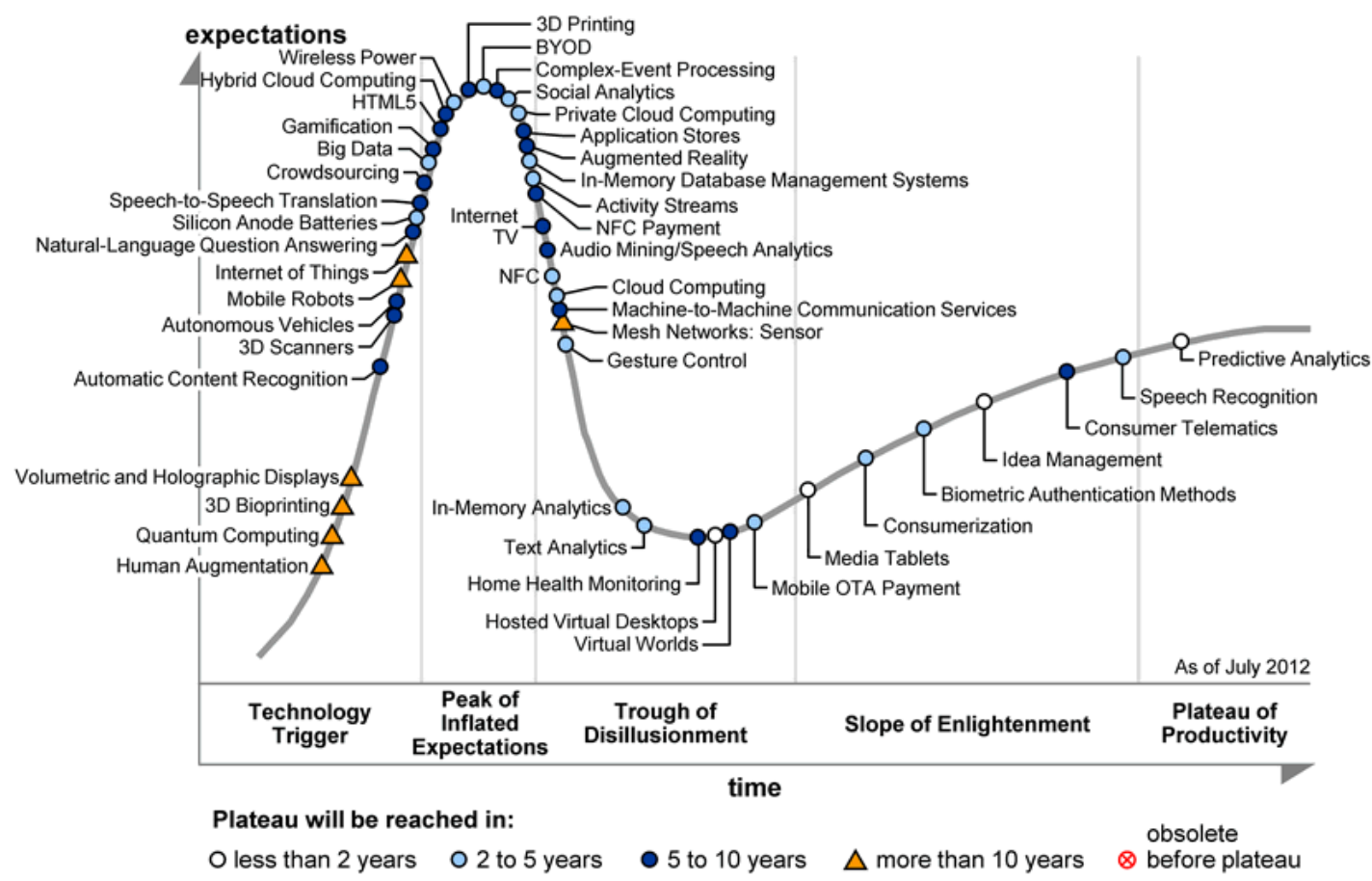

Figure. 1. Hype Cycle for Emerging Technologies 2012 produced by Gartner Inc.

While it has potential, the AM industry has been plagued by over-estimation and hype since its early years, a trend continued in more recent press. ${ }^{6}$ The Gartner Hype Curve or 'Hype Cycle for Emerging Technologies' is produced annually by an information technology research and advisory company, Gartner Inc. Their 2012 estimate shows 3D printing on the 'peak of inflated expectations'. Although many have labelled this

5 I Gibson, Additive Manufacturing Technologies Rapid Prototyping to Direct Digital Manufacturing. (2010) Springer, New York; N Hopkinson, R. Hague, and P Dickens, Rapid Manufacturing: An Industrial Revolution for the Digital Age (2006) John Wiley, Chichester, England; L Hao, S Mellor, O Seaman, J Henderson, N Sewell, and M Sloan, 'Material characterisation and process development for chocolate additive layer manufacturing' (2010) Virtual Phys. Prototyp. 5(2), 57-64.

${ }^{6}$ M Campbell, 'Absolutely fabricated: the sceptic's guide to 3D printing' (2012) New Sci. 216(2895) 46-9; R Ehrenberg, 'The 3-D printing revolution: Dreams made real, one layer at a time' (2013) Sci. News 183 (5), $20-5$. 
Citation: Li, P., Mellor, S, Griffin, J, Waelde, C, Hao, L and Everson, R, (2014) 'Intellectual property and 3D printing: a case study on 3D chocolate printing' 9 (4) Journal of Intellectual Property Law and Practice 322-332; Li, P., Mellor, S, Griffin, J, Waelde, C, Hao, L and Everson, R, (2014) 1 GRUR Int 97 (Gewerblicher Rechtsschutz und Urheberrecht, Internationaler Teil)

technology as being 'disruptive' and suggest it is a key enabler for a third industrial revolution, ${ }^{7}$ its impact to date in terms of global manufacturing has been at best modest. However, one area which has seen significant growth is that of personal 3D printers. These desktop machines are creating a new market made up of hobbyist and enthusiasts who able to 'print' three-dimensional products in their own homes. The growth of this market is illustrated in Figure $2 .{ }^{8}$ It is around these smaller desktop machines that our case study is based.

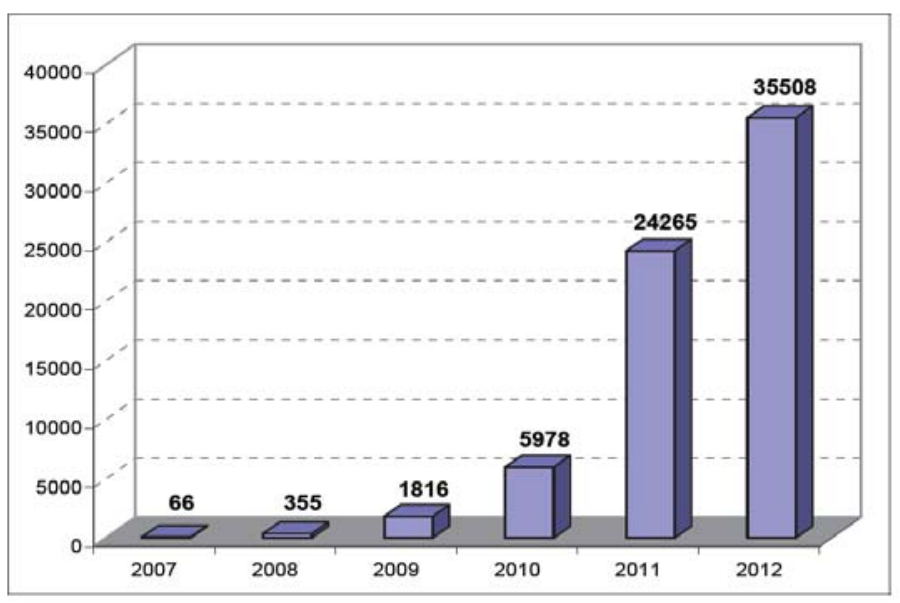

Figure. 2. Global sales of personal 3D printers, units '000s (original source Wohlers Associates)

3D printing using desktop machines could not only change manufacturing methods, it could also reshape business processes from the design of an object to its consumption. Consumer co-creation is increasingly used in the area of three-dimensional product development. In this process, the consumer is no longer passive; along with others she takes an interactive role in the design of the chocolates. She becomes a 'Prosumer' - a term coined to reflect that there is now a combination of producer and consumer.' Consumers may provide ideas for new products that fill needs not yet met by the market, or might improve on existing products. ${ }^{10}$ Adopting a consumer co-creation concept enables producers to shift their business model from manufacturing-centric mass

\footnotetext{
7 N Hopkinson, R Hague, and P Dickens, Rapid Manufacturing: An Industrial Revolution for the Digital Age (2006) John Wiley, Chichester, England.

8 'Solid Print: Making Things with a 3D Printer Changes the Rules of Manufacturing' (2012) The Economist, April.

9 D Tapscott, The Digital Economy: Promise and Peril in the Age of Networked Intelligence (1997) McGraw-Hill, US.

10 WD Hoyer, R Chandy, M Dorotic, M Krafft, and S Singh, 'Consumer Cocreation in New Product Development' (2010) J. Serv. Res. 13 (3) 283-96.
} 
Citation: Li, P., Mellor, S, Griffin, J, Waelde, C, Hao, L and Everson, R, (2014) 'Intellectual property and 3D printing: a case study on 3D chocolate printing' 9 (4) Journal of Intellectual Property Law and Practice 322-332; Li, P., Mellor, S, Griffin, J, Waelde, C, Hao, L and Everson, R, (2014) 1 GRUR Int 97 (Gewerblicher Rechtsschutz und Urheberrecht, Internationaler Teil)

production to consumer-centric mass innovation or customisation. ${ }^{11}$ Once co-created, the designs can be printed cost effectively using a 3D printer.

But this change in the business model, and engaging many individuals in the design process, brings with it challenges to existing IP laws and in particular, for our purposes, for the law of copyright. ${ }^{12}$ Under traditional mass production practice, producers or individual innovators would normally own the copyright in their products, and, as a result, hold exclusive control over the exploitation of the copyright value embodied in those products. Co-creation, by contrast, involves multiple actors including consumers and producers which introduces challenges for the identification of the author and owner of the copyright in the products. Relatedly, questions over the level of originality in the work, the copyright consequences of reproducing two-dimensional works in three-dimensions and vice versa, and of the potential liability of the provider of the 3D equipment for copyright infringement if the $3 \mathrm{D}$ printer is used to print three-dimensional products that infringe copyright, all need to be addressed if the potential of the technology is to be realised.

This paper will consider these copyright questions focussing on a case study of 3D chocolate printing that uses a co-creation business model. In the first part of the paper, a brief description is given of $3 \mathrm{D}$ chocolate printing technology, including the chocolate co-creation website platform developed by a research group at the University of Exeter. ${ }^{13}$ The second part of the paper will examine the areas of copyright identified above and apply these to the chocolate co-creation and 3D printing process. Finally the paper will briefly consider some of the strategies adopted in other lines of business where copyright challenges have arisen to ask whether any of the solutions used might be applied to our case study.

\section{THE COPYRIGHT IMPLICATIONS OF 3D PRINTING TECHNOLOGY}

As $3 \mathrm{D}$ printing is a relatively recent phenomenon, the law literature examining the IP implications of 3D printing is limited. Bradshaw et al. (2010); ${ }^{14}$ Weinberg (2010); $;^{15}$ and

\footnotetext{
11 E Hippel, 'Democratizing innovation: The evolving phenomenon of user innovation' (2005) J. Für Betriebswirtschaft 55 (1), 63-78.

12 A Sissons and S Thompson, 'Three Dimensional Policy: Why Britain needs a policy framework for 3D printing' (2012) Big Innovation Centre.

13 http:/ / www.bbc.co.uk/news/technology-17623424 (last accessed 30 Aug 2013).

14 S Bradshaw, A Bowyer, and P Haufe, 'The intellectual property implication of low-cost 3D printing' (2010) SCRIPT-ed 7(1).

15 M Weinberg, 'It would be awesome if they don't screw it up: 3D printing, intellectual property, and the fight over the next great disruptive technology' (2010) Public Knowledge.
} 
Citation: Li, P., Mellor, S, Griffin, J, Waelde, C, Hao, L and Everson, R, (2014) 'Intellectual property and 3D printing: a case study on 3D chocolate printing' 9 (4) Journal of Intellectual Property Law and Practice 322-332; Li, P., Mellor, S, Griffin, J, Waelde, C, Hao, L and Everson, R, (2014) 1 GRUR Int 97 (Gewerblicher Rechtsschutz und Urheberrecht, Internationaler Teil)

Mendis $(2013)^{16}$ have all published in this area each taking a particular perspective on the IP implications of 3D printing, and each of whom highlights some of the IP challenges that arise. Bradshaw, whose work spans each of the IP rights including copyright, patents, trade marks and design rights concludes that where 3D printing is carried out for non-commercial private purposes the IP framework throws up few barriers; Weinberg advises those exploring with the technologies in their garden sheds to keep an eye on the IP discussion as it could have implications for what they do; and Mendis counsels that where 3D products are to be commercially exploited, then we need to think about new business models.

This paper is more limited in its discussion. The focus is on narrow aspects of the law of copyright, chosen because of their relevance to our case study. Theseare:

-artistic works:

0 the copyright consequences of reproducing two dimensional works in three dimensions;

o the requirement of originality for the subsistence of copyright along with the problems posed by substantial taking from existing works;

0 the copyright implications of consumer/user co-creation of the chocolate designs; and

-liability for authorisation of infringement of copyright.

The focus is on copyright in general and on these aspects in particular because the issues that they raise are at the heart of the business model on which the design, reproduction and dissemination of the three-dimensional chocolate products is based. If the model is to 'work' then the risks associated with these aspects of the law must be assessed and decisions on business strategies developed accordingly. The law discussed will be that of the UK found in the Copyright Designs and Patents Act 1988 (CDPA), as amended. It is a piece of legislation that has been shaped by European Union (EU) and International obligations. ${ }^{17}$ However it should be noted that copyright law is not harmonised either at European or International level. That means that something that may infringe the law in the UK may not infringe in other territories and vice-versa, a point to be borne in

\footnotetext{
16 D Mendis, "The clone wars": episode 1 - the rise of 3D printing and its implications for intellectual property law - learning lessons from the past?' (2013) European Intellectual Property Review 35(3)155-169 17 The European obligations are found in a number of Directives promulgated by the EU. The International obligations are found in International Treaties such as the Berne Convention for the Protection of Literary and Artistic Works 1886 (as revised).
} 
Citation: Li, P., Mellor, S, Griffin, J, Waelde, C, Hao, L and Everson, R, (2014) 'Intellectual property and 3D printing: a case study on 3D chocolate printing' 9 (4) Journal of Intellectual Property Law and Practice 322-332; Li, P., Mellor, S, Griffin, J, Waelde, C, Hao, L and Everson, R, (2014) 1 GRUR Int 97 (Gewerblicher Rechtsschutz und Urheberrecht, Internationaler Teil)

mind if considering cross border creation and exploitation of 3D printing technologies and products. It should also be noted that these areas are in no way exhaustive of the copyright challenges that arise which are numerous.

Prior to analysing the law, the next part will describe and explain the case study.

\section{Case study on 3D chocolate printing}

This case study represents the experience of one of the authors of inventing a technology in the field of 3D printing, and of research in using a digital co-creation approach to the design of the products. Similar product creation and manufacturing processes are used with other $3 \mathrm{D}$ printing technologies such as plastic, metal and ceramic products and which are available in the current commercial market.

In 2007 Dr Liang Hao (Exeter University) had the idea of combining 3D printing and chocolate processing to develop a chocolate manufacturing technology capable of creating artistic and personalised chocolate products which could be sold to consumers. Engineering students at the University constructed an experimental chocolate additive layer manufacturing (ChocALM) prototype (3D chocolate printer). Following key technical developments, a spin-out company, Choc Edge Ltd, was set up to commercialise the technology. ${ }^{18}$ In April 2012, the company made the first 3D chocolate printer, 'the Choc Creator 1' and introduced it to the market. An overview of the printer is shown in Figure 3.

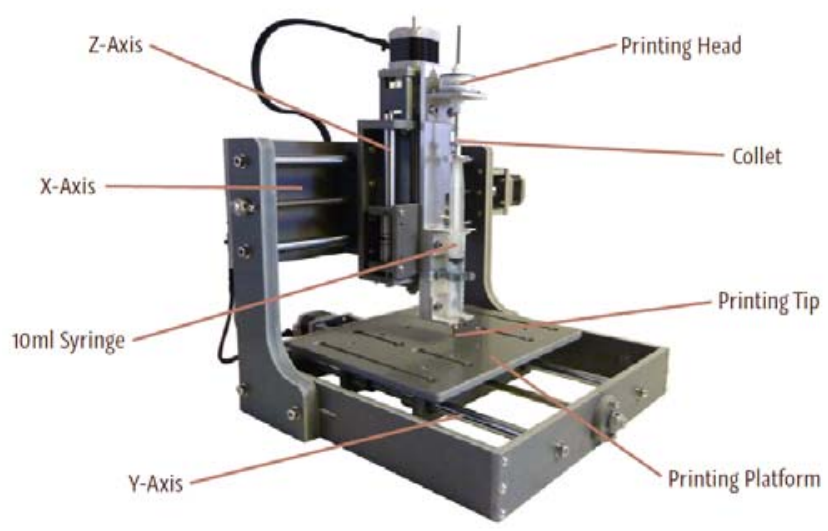

Figure. 3. Overview of Choc Creator $13 \mathrm{D}$ printer

18 Chocedge, http://www.chocedge.com/ (accessed 3 August 2013) 
Citation: Li, P., Mellor, S, Griffin, J, Waelde, C, Hao, L and Everson, R, (2014) 'Intellectual property and 3D printing: a case study on 3D chocolate printing' 9 (4) Journal of Intellectual Property Law and Practice 322-332; Li, P., Mellor, S, Griffin, J, Waelde, C, Hao, L and Everson, R, (2014) 1 GRUR Int 97 (Gewerblicher Rechtsschutz und Urheberrecht, Internationaler Teil)

This technology revolutionises the way in which chocolate producers can engage consumers in creating artistic and personalised chocolate designs and products through the process chain from design to product as described below:

\section{Step 1: Conceptualisation and digitisation of the three-dimensional design}

The product idea and design can be conceptualised and digitised through a variety of means. They can be: designed in 3D modelling software; reversed engineered through 3D scanning technology; from a 2D image converted to a three dimensional model; and designs can be downloaded from file sharing websites.

\section{Step 2: Conversion to STL file format}

The design or data generated in the previous step is then converted into a stereolithography file, or STL. The STL is a tessellated representation of the surfaces of the solid part of the design and is the most common file format for 3D printers.

\section{Step 3: Import STL design into system software}

The STL file is imported into the machine control software package. This case study uses software that is a modified version of the open source package called Replicator G.

\section{Step 4: Machine set-up}

Depending on the product features and specifications, the machine parameters are set up using the machine control software.

\section{Step 5: Three-dimensional printing of product}

The raw material is prepared, the chocolate is heated, tempered and loaded in the syringe system in the printer. Once loaded and located in the correct position, the manufacturing cycle is started. The G-Code generated by the software controls the movement of the stepper motor system according to the original model file. The design is built up in successive layers until the final layer is produced.

\section{Step 6: Product completion}

Once the manufacturing cycle has finished, the design is left to cool. It is then ready for eating or for distribution. 
Citation: Li, P., Mellor, S, Griffin, J, Waelde, C, Hao, L and Everson, R, (2014) 'Intellectual property and 3D printing: a case study on 3D chocolate printing' 9 (4) Journal of Intellectual Property Law and Practice 322-332; Li, P., Mellor, S, Griffin, J, Waelde, C, Hao, L and Everson, R, (2014) 1 GRUR Int 97 (Gewerblicher Rechtsschutz und Urheberrecht, Internationaler Teil)

\section{Coco Works}

The team at Exeter University has also developed a website, cocoworks.ex.ac.uk, ${ }^{19}$ to facilitate consumer co-creation of the designs. This website allows prosumers and designers to create chocolate products using a downloadable design tool. Based on Google Sketch-up, a unique add-on user interface has been developed through which users can rapidly and effectively design three-dimensional chocolate products even if they have little or no previous design experience. For example, Coco Works has a function tool offering an image-to-three-dimensions feature. Through a simple thresholding and extrusion process users can create a three-dimensional part file from a two-dimensional image file. Coco Works also provides the facility for designers to share their designs with other users who can vote for the designs and download and change them thus encouraging the co-creation of chocolate products. Users may also access the gallery of chocolate designs and order the physical product which in turn can be manufactured in the facility run by Choc Edge Ltd., or printed out using the Choc Creator 1 printers owned by the users. This process of chocolate product co-creation and production is illustrated in Figure 4.

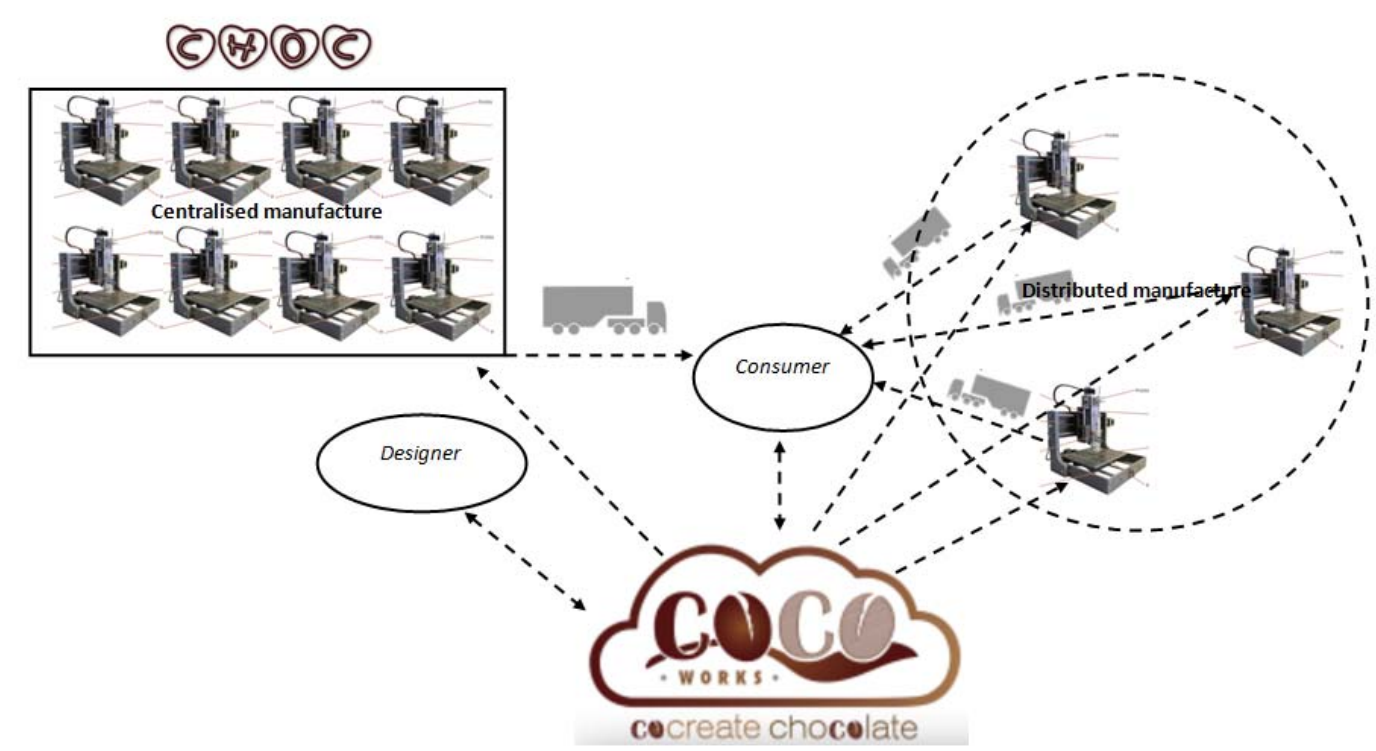

Figure. 4. Overview of 3D chocolate product co-creation and production process

\section{COPYRIGHT LAW, 3D PRINTING AND CO-CREATION}

As noted above, the focus in this paper is on artistic works and in particular on: (a) the

19 Coco Works, http://www.cocoworks.ex.ac.uk/ (accessed 3 August 2013) 
Citation: Li, P., Mellor, S, Griffin, J, Waelde, C, Hao, L and Everson, R, (2014) 'Intellectual property and 3D printing: a case study on 3D chocolate printing' 9 (4) Journal of Intellectual Property Law and Practice 322-332; Li, P., Mellor, S, Griffin, J, Waelde, C, Hao, L and Everson, R, (2014) 1 GRUR Int 97 (Gewerblicher Rechtsschutz und Urheberrecht, Internationaler Teil)

copyright implications of reproducing two-dimensional works in three dimensions; (b) the requirement of originality along with substantial taking from existing works; and (c) consumer/user co-creation and authorship/ownership of the chocolate designs. The liability of third parties for authorisation of infringement of copyright will also be considered.

\section{Artistic works}

The focus is on artistic works because the chocolate products made by the $3 \mathrm{D}$ printer as well as the designs for the products are most likely to fall under the legal definition of an artistic work. ${ }^{20}$ The category of artistic works in the CDPA, described as works which are visually significant or made to look at, ${ }^{21}$ includes a number of different types such as maps and plans. ${ }^{22}$ The most relevant for our purposes are sculptures, ${ }^{23}$ drawings and works of artistic craftsmanship. Graphic works are a particularly expansive copyright category and examples in the case law have included: icons used in the displays on a computer program; ${ }^{24}$ architects' plans; ${ }^{25}$ sketches of garments; ${ }^{26}$ engineering and machine part drawings; ${ }^{27}$ cartoon characters; ${ }^{28}$ and trade mark and label designs. ${ }^{29}$,Looking at the Coco Works website it is easy to see that the images represented there are artistic works - one example is this image of a footballer by Liang Ho (Figure $5)$ :

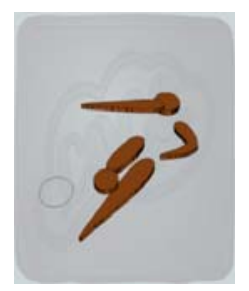

Figure 5. Footballer by Liang Hao

\footnotetext{
20 CDPA s 4.

21 Anacon Corp v Environmental Research Technology [1994] F.S.R. 659 , applying Interlego AG v Tyco Industries Ltd [1988] R.P.C. 343 at 373, per Lord Oliver.

22 A graphic work includes a painting, drawing, diagram, map, chart, or plan, and any engraving, etching, lithograph, woodcut, print, or similar work. See further T Rychlicki, 'Legal questions about illegal art. 3' (2008) JIPLP 393.

23 This is irrespective of artistic quality.

24 Navitaire Inc v EasyJet Airline Co Ltd [2006] RPC 3 (Pumfrey J).

25 See, eg, Robert Allan \& Partners v Scottish Ideal Homes 1972 SLT (Sh Ct) 32.

26 See, eg, Howard Clark v David Allan \& Co Ltd 1987 SLT 271.

27 See, eg, British Leyland v Armstrong Patents [1986] AC 577.

28 King Features Syndicate Inc v OM Kleeman Ltd [1941] AC 417 (Popeye the Sailorman).

${ }_{29}$ KARO STEP Trade Mark [1977] RPC 255. Other works that have been protected as artistic works include photographs of antiques and of individuals Case C-145/10 Painer v Standard Verlags GmbH [2012] ECDR 6
} 
Citation: Li, P., Mellor, S, Griffin, J, Waelde, C, Hao, L and Everson, R, (2014) 'Intellectual property and 3D printing: a case study on 3D chocolate printing' 9 (4) Journal of Intellectual Property Law and Practice 322-332; Li, P., Mellor, S, Griffin, J, Waelde, C, Hao, L and Everson, R, (2014) 1 GRUR Int 97 (Gewerblicher Rechtsschutz und Urheberrecht, Internationaler Teil)

What copyright category it falls into is an interesting question. It does not have the feel of a drawing. Perhaps it would be considered a collage as a number of elements have been brought together to make the one figure; $;^{30}$ or maybe a graphic work because of the diversity of works encompassed within it. Once made into chocolate, 'sculpture' might be a suitable copyright category to describe the chocolates as might work of 'artistic craftsmanship'. For this latter category, there is somewhat mixed case law on what would qualify as a work of artistic craftsmanship. It seems that a work must be of a quality making it capable of being described as artistic ${ }^{31}$ which would not be problematic for these chocolates. But what about the requirement of 'craftsmanship'? Would producing a chocolate by way of a 3D printer preclude this category? It is difficult to see why it should. A craftsman uses tools such as hammers and nails; knitting needles; ${ }^{32}$ and machines for shaping objects. ${ }^{33}$ A $3 \mathrm{D}$ printer is simply another type of tool.for producing a work of artistic craftsmanship.

However, it may be that this is a moot point. As will be explained below, developments in case law from the European Court of Justice (CJEU) arguably point to the fact that it might no longer be necessary for a work to fall within a particular copyright category; rather, the emphasis is on the right form of authorial input. ${ }^{34}$

\section{The reproduction of two-dimensional artistic works in three dimensions and vice versa}

What is relevant about an artistic work for 3D printing is that representing a two-dimensional artistic work in three dimensions is a reproduction for the purposes of copyright infringement, as is representing a three-dimensional work in two dimensions. ${ }^{35}$ So, for example, a drawing of a cartoon figure protected by artistic copyright which is represented in three dimensions in chocolate is a reproduction of the drawing for the purposes of copyright. ${ }^{36}$ Similarly, a three-dimensional cartoon character protected by artistic copyright represented in the form of a flat chocolate is also reproduction for the

\footnotetext{
30 H MacQueen, C Waelde, G Laurie, and A Brown, Contemporary Intellectual Property: Law and Policy (2010)

Oxford University Press, Oxford, UK, para 2.80

31 George Hensher Ltd. v Restawile Upholstery (Lancs) Ltd., [1976] AC 64.

32 Bonz Group v Cooke [1994] 3 NZLR 216

33 Lucasfilm v Ainsworth [2009] FSR 2.

34 Case C-5/08 Infopaq International A/S v Danske Dagblades Forening (Infopaq; Handig, C "The "sweat of the brow" is not enough! - more than a blueprint of the European copyright term 'work", 2013, EIPR 334

35 CDPA 1988, s 17(3).

36 King Features Syndicate Inc v O. \& M. Kleeman Ltd [1941] A.C. 417. BBC Worldwide Ltd v Pally Screen Printing Ltd [1998] F.S.R. 665.
} 
Citation: Li, P., Mellor, S, Griffin, J, Waelde, C, Hao, L and Everson, R, (2014) 'Intellectual property and 3D printing: a case study on 3D chocolate printing' 9 (4) Journal of Intellectual Property Law and Practice 322-332; Li, P., Mellor, S, Griffin, J, Waelde, C, Hao, L and Everson, R, (2014) 1 GRUR Int 97 (Gewerblicher Rechtsschutz und Urheberrecht, Internationaler Teil)

purposes of copyright. ${ }^{37}$ These reproductions in turn are within the exclusive rights of the owner of the copyright in the artistic work. If anyone makes a reproduction of the artistic work without the consent of the owner(s), that infringes copyright. To be non-infringing, consent of all of the owners is needed.

\section{Who is the owner of the copyright?}

The question then arises as to who is the owner of the copyright ${ }^{38}$ To answer this it must be determined whether the work is original. ${ }^{39}$ This is important because it is the author who is the person who puts the right kind of originality into a work for copyright to subsist. Once these hurdles have been overcome, it will be possible to identify the author. $^{40}$ Often then (but not always) the author is the owner of the copyright.

\section{Originality}

For copyright to subsist there must be the appropriate creative effort or originality present in the artistic work. Historically, the law only required that a work not be copied, but no more than skill, judgement or labour needed to be expended in its creation. ${ }^{41}$ What skill is applied must be relevant to the work as it is expressed, rather than to the idea behind the work (which remains unprotectable). Such was the low level of originality required in the UK, that few works had been denied the status of a 'work' for want of originality, resulting in the protection of decorative lines on a parcel, ${ }^{42}$ and a hand with a finger pointing to a ballot paper, ${ }^{43}$ by copyright. However, recent case law from the CJEU suggests that the originality requirement may be changing in a way that appears to conflate the concept of the work and the requirement of originality. ${ }^{44}$ The CJEU has stressed that the European scheme of protection for copyright protects works where the subject matter is original in the sense of being the author's intellectual

\footnotetext{
37 CDPA 1988, s 17(3).

38 CDPA s 11.

39 CDPA s 1(1)(a)

40 CDPA s 9.

41 University of London Press [1916] 2 Ch 601.

42 Walker v British Picker [1961] RPC 57

43 Kenrick \& Co v Lawrence \& Co (1890) 25 Q.B.D. 99.

44 van Eechoud, M, 'Along the road to uniformity - diverse readings of the Court of Justice Judgments on copyright work' 3 (2012) JIPITEC 60; Handig, C 'The "sweat of the brow" is not enough! - more than a blueprint of the European copyright term 'work", 2013, EIPR 334; Rahmatian, A, 'Originality in UK copyright law: the old "skill and labour" doctrine under pressure', 2013 IIC 3; Rosati, E, 'Towards an EU-wide copyright? (Judicial) pride and (legislative) prejudice', 2013 IPQ 46; J Pila, 'An intentional View of the Copyright Work' (2008) Modern Law Review 71; C Handig, "Infopaq International A/S v Danske Dagblades Forening (C-5/08): is the term "work" in the CDPA 1988 in line with the European Directives?" (2010) EIPR 32(2), 53
} 
Citation: Li, P., Mellor, S, Griffin, J, Waelde, C, Hao, L and Everson, R, (2014) 'Intellectual property and 3D printing: a case study on 3D chocolate printing' 9 (4) Journal of Intellectual Property Law and Practice 322-332; Li, P., Mellor, S, Griffin, J, Waelde, C, Hao, L and Everson, R, (2014) 1 GRUR Int 97 (Gewerblicher Rechtsschutz und Urheberrecht, Internationaler Teil)

creation. ${ }^{45}$ What the work is called, in other words for our purposes whether it is an artistic work, a drawing, works of artistic craftsmanship or collage, is irrelevant, although it seems that a work would need to fall under the Berne Convention categories of a literary or artistic work. ${ }^{46}$ The standard of originality for all types of work is the same: it is one of intellectual creation. ${ }^{47}$ To reach this level the author should express her creative ability in an original manner by making free and creative choices, ${ }^{48}$ and stamp her 'personal touch' on the work. ${ }^{49}$ Where choices are dictated by technical considerations, rules or constraints which leave no room for creative freedom, then these criteria are not met. ${ }^{50}$

If we look at Liang Hao's footballer, there seems little doubt that the threshold of originality would be reached sufficient for copyright to subsist - no matter whether or not it fell into one of the CDPA categories. However, there is a caveat which is particularly pertinent to the ideals of co-creation. And that is whether an artistic work is a substantial copy of an existing work.

\section{Artistic work and substantial copying}

Another requirement of originality is that a work must not be copied from another. ${ }^{51}$ If a substantial part of another work is taken, then the copyright in that first work will be infringed. So when designing the artistic works on cocoworks.ex.ac.uk if the consumer starts with an existing three dimensional artistic work - the cartoon character for example - and combines it with a two-dimensional image file for printing a

45 Case C-5/08 Infopaq International A/S v Danske Dagblades Forening (Infopaq) paras 33 38. See also Case C -393/09 Bezpečnostní softwarová asociace para 45 What is not protected is expression which is limited by its technical function. Case C- 406/10 SAS Institute Inc. v World Programming Ltd paras 38-40. Case C-145/10, Painer v Standard VerlagsGmbH et al In the UK see SAS Institute Inc.v World Programming Ltd [2013] EWHC 69 (Ch) para 27.

46 Berne Convention Article 2(1). SAS Institute Inc v World Programming Limited [2013] EWHC 69 (Ch) para 27.

47 Case C-5/08 Infopaq International A/S v Danske Dagblades Forening, , Case C-393/09 Bezpečnostní softwarová asociace paragraph 45; Joined Cases C-403/08 and C-429/08 Football Association Premier League and Others; Rosati, E, 'Originality in a work, or a work of originality: the effects of the Infopaq decision’ E.I.P.R. 2011, 33(12), 746. Derclaye, E, ‘Wonderful or Worrisome? The Impact of the ECJ Ruling in Infopaq on UK Copyright Law' (2010) EIPR 32(5), 248.

\footnotetext{
48 Infopaq, para 45; Bezpečnostni softwarová asociace, para 50; Painer, para 89, Football Dataco para 38

49 Painer, para 92; Football Dataco para 38.

50 Bezpećnostni softwarová asociace, paras 48 and 49, Football Association Premier League and Others, para 98; Football Dataco para 39. See also the articles at fn 53.

51 Interlego v Tyco [1988] RPC 343.
} 
Citation: Li, P., Mellor, S, Griffin, J, Waelde, C, Hao, L and Everson, R, (2014) 'Intellectual property and 3D printing: a case study on 3D chocolate printing' 9 (4) Journal of Intellectual Property Law and Practice 322-332; Li, P., Mellor, S, Griffin, J, Waelde, C, Hao, L and Everson, R, (2014) 1 GRUR Int 97 (Gewerblicher Rechtsschutz und Urheberrecht, Internationaler Teil)

three-dimensional chocolate, then both the two-dimensional file and the three-dimensional chocolate will infringe copyright in the original artistic work. Further, it is not necessary for the copy to be exact to infringe; only that a substantial part is taken from the first in creating the second. Here, 'substantial' is largely a qualitative as opposed to a quantitative test. For example, and using Liang Hao's footballer as an illustration, if consumers copy it but alter it in various ways - perhaps a change in the position of an arm, and of the ball, the addition of an embellishment or two - that would still be an infringement of copyright in Liang's artistic work. So the two-dimensional design copied from Liang's original work would infringe, as would the ultimate three-dimensional printed chocolate.

Commonplace artistic techniques and skills are not generally protected by copyright so if these are the elements that are copied then there will be no infringement. But once it has been found that a substantial part has been taken it makes no difference that a different medium is used (chocolate as opposed to a computer file), or that the infringing work is derived indirectly from the original work, such as where an intermediary has given verbal instructions which are used by a third party to recreate the work. It will still be an infringement if the size changes; ${ }^{52}$ dimensions are altered $;^{53}$ elements of the original work are left out or bits added; ${ }^{54}$ or where the differences are only minor or trivial. $^{55}$

Perhaps reassuringly, simple artistic works only have thin copyright protection. ${ }^{56}$ This means that where a simple artistic work is protected by copyright - such as a bauble or a Christmas tree - then only an almost exact copy will result in infringement. Taking an example from the cocoworks.ex.ac.uk website of the Christmas bells (Figure 6):

\footnotetext{
52 Johnstone Safety Ltd v Peter Cook (Int.) Plc [1990] F.S.R. 16; Auvi Trade Mark [1995] F.S.R. 288; Antiquesportfolio.com v Rodney Fitch \& Co Ltd [2001] F.S.R. 345.

53 Wham-O Manufacturing Co v Lincoln Industries Ltd [1985] R.P.C. 127 (CA of NZ); Johnstone Safety Ltd v Peter Cook (Int.) Plc [1990] F.S.R. 161; Alan Nuttall v Equipashop Ltd, noted at [1992] I.P.D. 15097 (what is substantial cannot be defined by inches or measurement).

54 Brooks v Religious Tract Society (1897) 45 W.R. 476.

55 British Northrop Ltd v Texteam Blackburn Ltd [1973] F.S.R. 241 ; S.W. Hart \& Co Pty Ltd v Edwards Hot

Water Systems [1986] F.S.R. 575; Interlego A.G. v Tyco Industries Inc [1987] F.S.R. 409.

56 Kenrick \& Co v Lawrence \& Co (1890) 25 Q.B.D. 99.
} 
Citation: Li, P., Mellor, S, Griffin, J, Waelde, C, Hao, L and Everson, R, (2014) 'Intellectual property and 3D printing: a case study on 3D chocolate printing' 9 (4) Journal of Intellectual Property Law and Practice 322-332; Li, P., Mellor, S, Griffin, J, Waelde, C, Hao, L and Everson, R, (2014) 1 GRUR Int 97 (Gewerblicher Rechtsschutz und Urheberrecht, Internationaler Teil)

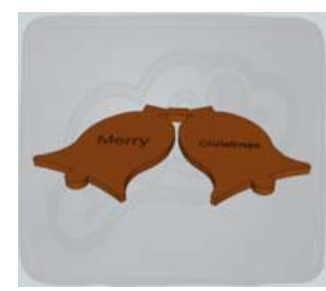

Figure 6 Christmas Bells by Liang Hao

While the design will attract copyright protection, only an almost exact replica will infringe. So that would leave it open to a third party to design their own Christmas bells, perhaps in a slightly different shape, or at a slightly different angle.

It should also be remembered that copyright is concerned with copying. If two authors come up with the same or very similar artistic works independently, such as drawings of bells, and one has not been copied from the other, then there will be no infringement of copyright.

\section{And so....}

Having decided on the artistic work, and that the originality criterion is satisfied, the next step is to decide who the author is and, relatedly, who owner of the copyright in the work is.

\section{The author(s)}

\section{Co-creation and $3 D$ printing}

As will be seen from the description above of the process of developing designs for the three-dimensional printed chocolate products, consumer engagement is a central element. The website, cocoworks.ex.ac.uk, enables consumers to convert images from two dimensions to three dimensions, to share and manipulate those images, and then to print the three-dimensional chocolate products either using their own 3D printers or via Choc Edge's facilities. What, then, does the law of copyright say about the co-creation aspect, and in particular authorship and ownership of the copyright?

Copyright law was originally designed to protect text and the individual author. ${ }^{57}$ While it has expanded over the years to protect many different forms of creative works, it remains a challenge for the law to accept that there are works where there are more than one, or at the most two, authors of a work. This causes difficulties for co-creation

57 Statue of Anne 1709 
Citation: Li, P., Mellor, S, Griffin, J, Waelde, C, Hao, L and Everson, R, (2014) 'Intellectual property and 3D printing: a case study on 3D chocolate printing' 9 (4) Journal of Intellectual Property Law and Practice 322-332; Li, P., Mellor, S, Griffin, J, Waelde, C, Hao, L and Everson, R, (2014) 1 GRUR Int 97 (Gewerblicher Rechtsschutz und Urheberrecht, Internationaler Teil)

processes where multiple individuals engage in the development and each has some form of authorial input. The test for joint authorship is that there must be a work produced by the collaboration of two or more authors in which the contribution of each author is not distinct from that of the other author or authors when you look at the final work. ${ }^{58}$ What is important is collaboration between authors in the execution of a work although no common intent is needed. ${ }^{59}$ However contributing only ideas is not enough ${ }^{60}$ there must be input into the expression of the idea - i.e. the work itself.

So what about the activities of the co-creators on cocoworks.ex.ac.uk? It would seem that the contributions to the designs of the artistic works will not be distinct. In other words, one would not be able to point to one part and say X contributed that part and then to another and say ' $\mathrm{Y}$ ' contributed that part. It also seems that the creators will have collaborated in the execution of the work - the design for the chocolate product. So long as each has put in the right sort of input to the work and not just ideas, then all of those who have contributed will be joint authors.

Identifying who is the author of a work is important because it is from authorship that ownership usually flows. The copyright legislation provides that the first owner of the copyright in a work is the author. ${ }^{61}$ This is unless the work has been made in the course of employment. If this is the case then, subject to any agreement to the contrary, the employer is the owner of the copyright. In turn, who is the owner of the copyright is critical, as it is the owner who has the exclusive rights to exploit the work through acts of reproduction (copying), adaptation (changing the work into something else) and dissemination (circulating copies to the public) along with other rights. Anyone who does or performs any of these exclusive rights without the consent of the copyright owner infringes copyright.

Every owner has a right to manage the copyright in that consent of each owner has to be obtained to licence the work, ${ }^{62}$ and to sell the work, ${ }^{63}$ and each owner can pass on their share to their heirs. ${ }^{64}$ Therefore, with possible multiple owners of the copyright, the

\footnotetext{
58 CDPA 1988, s 10(1)

59 Beckingham v Hodgens [2004] E.C.D.R. 6; [2003] E.M.L.R. 18

${ }^{60}$ Fylde Microsystems Ltd v Key Radio Systems Ltd [1998] FSR 449. Compare Brown v Mcasso Music Production

Ltd (PCC) Patents County Court [2005] F.S.R. 40

61 CDPA 1988, s.11(1).

62 Powell v Head (1879) 12 Ch D 686; Mail Newspapers v Express Newspapers [1987] FSR 90.

63 CDPA 1988, s 173(2).

64 Lauri v Renad (1892) 3 Ch 402; Slater v Wimmer [2012] EWPCC 7 (PCC) at para 89
} 
Citation: Li, P., Mellor, S, Griffin, J, Waelde, C, Hao, L and Everson, R, (2014) 'Intellectual property and 3D printing: a case study on 3D chocolate printing' 9 (4) Journal of Intellectual Property Law and Practice 322-332; Li, P., Mellor, S, Griffin, J, Waelde, C, Hao, L and Everson, R, (2014) 1 GRUR Int 97 (Gewerblicher Rechtsschutz und Urheberrecht, Internationaler Teil)

challenges to identify those individuals and employer organisations who own the copyright, and to get agreement over patterns of exploitation, becomes intensely complicated.

The process can be appreciated if we consider the artistic work in the above Figure 5 taken from the Coco Works website. What can we say about authorship and ownership of the copyright in this work and the ultimate three-dimensional chocolate products? In working on the image files, sharing designs, inputting their own skill, labour and effort and imprinting their own personal stamp on the work, so each individual may have put in the authorial effort necessary to be seen as an author of the copyright. It is likely that the contributions in the end product would be indistinguishable, so each would be a joint author. Whether any employer would be a joint owner would depend on the employment status of the contributors. The result is that there could be many individuals and organisations who could be considered to be one of the co-authors and owners of the design and the ultimate three-dimensional chocolate - making the exploitation situation highly complex.

\section{Term of protection}

So how long does copyright in the artistic works and three-dimensional chocolate products last? A long time: for 70 years after the end of the calendar year in which the last joint author dies. ${ }^{65}$ So not only is it important to identify the authors for the purpose of knowing who owns the copyright and therefore who needs to be asked for permission to exploit the designs and sell the chocolates, but in addition it is necessary to know who the authors are to be able to tell how long the right lasts. Where you have multiple authors some of whose whereabouts may not be known or whose details may have been lost, it becomes clear how complex it can be when trying to manage co-creation processes and copyright.

\section{Authorisation of infringement}

The final copyright question for this paper is around authorisation of infringement. This occurs when one party authorises another in the eyes of the law to commit copyright infringement. ${ }^{66}$ When this happens the authoriser is also liable for

${ }^{65} \mathrm{CDPA}$ s 12 . When an artistic work had been exploited by an industrial process, then 25 years after that exploitation copyright is no longer enforceable. CDPA s 52. Copyright (Industrial Processes and Excluded Articles) (No 2) Order 1989 SI 1989/1070) art 3(1)) An example might be where 50 or more copies of a ring are made. This section is repealed by the Enterprise and Regulatory Reform Act 2013 s74. The repeal come into force after consultation with stakeholders.

66 The copyright in a work is infringed by any person who, without the licence of the copyright owner, 
Citation: Li, P., Mellor, S, Griffin, J, Waelde, C, Hao, L and Everson, R, (2014) 'Intellectual property and 3D printing: a case study on 3D chocolate printing' 9 (4) Journal of Intellectual Property Law and Practice 322-332; Li, P., Mellor, S, Griffin, J, Waelde, C, Hao, L and Everson, R, (2014) 1 GRUR Int 97 (Gewerblicher Rechtsschutz und Urheberrecht, Internationaler Teil)

infringement. Typically this occurs where one party provides equipment or facilities for another and these are used to infringe copyright. For example, the supply of a film of a play for exhibition at a cinema was held to authorise infringement of the copyright in the play where no permission had been given by the owner of the copyright in the play to film it; ${ }^{67}$ when a customer ordered spare parts from a manufacturer by reference to drawings, he was found to have authorised the manufacturer to infringe the copyright in drawings of those spare parts; ${ }^{68}$ and the prior approval by a local authority of the list of musical works to be played on a public bandstand was held to be an authorisation of infringement of the copyright in those musical works. ${ }^{69}$

For our example, there are two questions:

If the $3 \mathrm{D}$ chocolate printer is used to print out three-dimensional chocolates that infringe copyright, would the provision of the $3 \mathrm{D}$ printer amount to authorisation of infringement?

If the Coco Works website is used by the co-creators to develop designs for chocolates which infringe copyright, if for example, they use pre-existing designs, would the provision of the website amount to authorisation of infringement?

In both cases, who would be liable?

In law, to authorise an infringement of copyright is to 'sanction, approve, or countenance' the infringement. ${ }^{70}$ This is a formulation capable of a very wide meaning, especially when joined with the apparent willingness of the courts to treat indifference as capable of being authorisation. ${ }^{71}$ While creating opportunities for others to infringe, for example by providing machinery (in this case the $3 \mathrm{D}$ printer or the website), is not of itself authorisation especially when it can also be used for legitimate purposes (printing non-infringing chocolate designs for example), where there is both the provision of the opportunity to infringe (the 3D printer and/or the website) and a degree of control over the infringers (an ability to say who can use the website and/or print out chocolates perhaps) and specific instances of infringement, then there may be liability for

authorises another person to do any of the restricted acts.CDPA 1988, s 16(2).

67 Falcon v Famous Players Film Co [1926] 2 KB 474.

68 Standen Engineering v Spalding \& Sons [1984] FSR 554.

69 PRS v Bray UDC [1930] AC 377 (PC).

70 This definition of 'authorise' was first stated in Monckton v Pathe Freres Pathephone Ltd [1914] 1 KB 395 and Evans v Hulton \& Co Ltd [1924] WN 130.

${ }^{71}$ PRS v Ciryl Theatrical Syndicate [1924] 1 KB 1; Moorbouse v University of New South Wales [1976] RPC 151

(HCA); CBS v Ames Record \& Tapes [1982] Ch 91; PRS v Kwik-Fit Group Ltd [2008] ECDR 2. 
Citation: Li, P., Mellor, S, Griffin, J, Waelde, C, Hao, L and Everson, R, (2014) 'Intellectual property and 3D printing: a case study on 3D chocolate printing' 9 (4) Journal of Intellectual Property Law and Practice 322-332; Li, P., Mellor, S, Griffin, J, Waelde, C, Hao, L and Everson, R, (2014) 1 GRUR Int 97 (Gewerblicher Rechtsschutz und Urheberrecht, Internationaler Teil)

infringement. ${ }^{72}$ In a recent adjudication by the Advertising Standards Authority an independent UK regulator for advertising, it was found that an advertisement that encouraged purchasers to copy their library of CDs to a CD player encouraged users to break the law because it did not warn them that this form of copying was an infringement of copyright where it was carried out without permission of the owner. ${ }^{73}$

So for Choc Edge Ltd and for the owners of the Coco Works website it would appear that liability for authorising infringement of copyright is a possibility if the facilities are used to infringe copyright where such infringement could be prevented and it is known that there has been infringement.

Would adding a notice to the Coco Works website and on the 3D printer saying 'do not infringe copyright' absolve Choc Edge of any liability that might arise? The courts have said that appropriately worded notices which restricted what users could do with the facilities might mean that liability could be avoided. ${ }^{74}$ However, even if there is a notice, if copying continues and the person who is able to control the copying is indifferent to it, then there will be liability for authorisation. ${ }^{75}$ So if the $3 \mathrm{D}$ printer and Coco Works are used to infringe, this continues, and Choc Edge and the owner of the website know about it, even if there are notices, they may well be found liable for authorisation of infringement.

\section{CONCLUSION}

The discussion above highlights that there are significant issues around the law of copyright that Choc Edge needs to be aware of to ensure that its business model stays within the boundaries of the law. Or if that is not possible, then Choc Edge should be in a position to assess the risks of choosing one pathway over another.

Where there are multiple contributors to creative works, different models have been chosen by businesses over the years facing just such dilemmas. One option might be to make all of the designs that are developed on Coco Works open source. So if people wanted to co-design chocolate products then they would allow others to do what they wanted with their work. Of course that would not negate any liability for infringement

\footnotetext{
72 Moorhouse v University of New South Wales [1976] RPC 151 (HCA) Compare CBS v Ames Records \& Tapes [1982] Ch 91, where no copying machines were provided.

73 http://asa.org.uk/Rulings/Adjudications/2011/3/3GA-Ltd/TF ADJ 50026.aspx. (Accessed 30 Aug 2013).

${ }_{74}$ Moorhouse v University of New South Wales [1976] RPC 151 (HCA).

75 Moorhouse v University of New South Wales [1976] RPC 151 per Jacobs J at 166.
} 
Citation: Li, P., Mellor, S, Griffin, J, Waelde, C, Hao, L and Everson, R, (2014) 'Intellectual property and 3D printing: a case study on 3D chocolate printing' 9 (4) Journal of Intellectual Property Law and Practice 322-332; Li, P., Mellor, S, Griffin, J, Waelde, C, Hao, L and Everson, R, (2014) 1 GRUR Int 97 (Gewerblicher Rechtsschutz und Urheberrecht, Internationaler Teil)

of copyright if third party works are used without permission as the source for the design. But assuming that is not the case it would make the process of exploitation more manageable as anyone could then use and adapt the designs and print off the chocolates without fear of liability. Another method might be to say that all the copyright in the designs for the works created on the Coco Works website belongs to Choc Edge. Once again that would not absolve participants from liability if infringing designs were used in the first place, but assuming that was not the case, it would mean that Choc Edge would own the copyright in the three-dimensional chocolates and could therefore exploit them in the marketplace knowing that they were not infringing. However that would require the creators to engage in the creative design process knowing that what they created would be owned by someone else. Would the creators be willing to engage in such circumstances particularly if Choc Edge them makes money from their efforts? The creators could of course be rewarded in other ways through some sort of benefit sharing. The law already provides some comfort in some circumstances - but not (yet) for 3D printing. For instance where the rental right in a film or sound recording belonging to the author or performer is transferred to a producer, the author or performer has a right to equitable remuneration. Could a similar scheme of equitable remuneration be conceived of for participants on the Coco Works website? There seems no reason why not. Other strategies to reward the creators efforts might be to credit co-creators individually on the Coco Works website for instance. But it is quite an 'ask' that creators should spend time and effort where the financial return goes elsewhere.

Other ways in which collective bargaining comes into its own is where there are many contributors to a particular project. For instance, films: there are many performers who are engaged on films. Obtaining their consent individually to exploitation of the performance would be extremely challenging. Often strong collective bargaining mechanisms have emerged, such as Equity ${ }^{76}$ and DACS. ${ }^{77}$ One can envisage similar schemes might work for 3D printing: all the co-creators could agree to standard ways in which their works could be exploited. It is likely however to require critical mass in the market.

In terms of giving comfort to the user of copyright works, a series of collective licensing schemes have been developed over the years. For example, there is a collective licence

\footnotetext{
76 http://www.equity.org.uk/home/ (last accessed 30 Aug 2013).

77 http://www.dacs.org.uk/ (last accessed 30 Aug 2013).
} 
Citation: Li, P., Mellor, S, Griffin, J, Waelde, C, Hao, L and Everson, R, (2014) 'Intellectual property and 3D printing: a case study on 3D chocolate printing' 9 (4) Journal of Intellectual Property Law and Practice 322-332; Li, P., Mellor, S, Griffin, J, Waelde, C, Hao, L and Everson, R, (2014) 1 GRUR Int 97 (Gewerblicher Rechtsschutz und Urheberrecht, Internationaler Teil)

available from the Copyright Licensing Agency that allows users who photocopy journal articles and similar publications to photocopy them lawfully so long as they have a licence. ${ }^{78}$ That of course is only relevant for the publishers who have signed up to the scheme; many have and it does allow reasonable comfort to the licensee as to what and how much can be copied without risking being sued. This might provide food for thought where existing artistic works are to be used - but it would require the consent of the original artists to agree to such a scheme.

Mechanisms of copyright licensing are currently under review in both Europe ${ }^{79}$ and the $\mathrm{UK}^{80}$ as it is perceived that licensing may well be a solution to the challenges raised by copyright and digitisation. In the UK we have the copyright licensing steering group ${ }^{81}$ overseeing a number of initiatives seeking to streamline copyright licensing including licensing data, licences for educational purposes, and licenses for images and metadata. In Europe there is the Licences for Europe initiative ${ }^{82}$ looking at, among other things, user generated content. One could imagine a stream in both of these thinking about the issues surrounding 3D printing and how licensing solutions might help with the legal morass faced by stakeholders.

Our case study has ramifications for the commercial exploitation of 3D printing technologies and their outputs more generally, especially in the area of consumer products. The economic opportunities could be significant if a workable and supportive copyright system could be developed - one which had the confidence of all stakeholders.

\section{Acknowledgement}

Financial support by University of Exeter is gratefully acknowledged. This article is under the 'Bridging the Gaps: The Exeter Science Exchange' project. An earlier version of this paper was presented at 'Bridging the Gaps: The Exeter Science Exchange Workshop - 3D-Printing Workshop: Legal Challenges', 5 Oct 2012, Exeter University.

\footnotetext{
78 http://www.cla.co.uk/ (accessed 30 Aug 2013)

79 http://europa.eu/rapid/press-release SPEECH-12-923 en.htm (accessed 30 Aug 2013)

$80 \mathrm{R}$ Hooper, Rights and Wrongs: Is Copyright Licensing Fit For Purpose in the Digital Age? The First Report of the Digital Copyright Exchange Feasibility Study (London, 2012); R Hooper and R. Lynch Copyright Works: Streamlining Copyright Licensing for the Digital Age (London, 2012).

http://www.ipo.gov.uk/types/hargreaves/hargreaves-copyright/hargreaves-copyright-dce/hargreaves-copy right-dce-terms.htm (accessed 12th June 2013)

81 http://www.clsg.info/CLSG_Home.php (accessed 30 Aug 2013)

82 http://ec.europa.eu/licences-for-europe-dialogue/en/content/about-site (accessed 30 Aug 2013)
} 